\title{
The functioning of the oesophageal groove reflex and comparison of the performance of lambs fed individually and in groups
}

\author{
By M. J. LAWLOR AND S. P. HOPKINS \\ Animal Nutrition and Biochemistry Department, \\ The Agricultural Institute, Dunsinea, Castleknock, Co. Dublin \\ AND J. K. KEALY \\ Department of Veterinary Surgery, University College, Dublin \\ (Received 7 December, 1970-Accepted 3 May 1971)
}

\begin{abstract}
I. Two experiments involving 106 lambs were conducted to study the functioning of the oesophageal groove reflex in lambs sucking from either individual feeders or from a bulk dispenser. The effects on the performance of lambs given either a high-protein or a lowprotein creep feed in conjunction with either a ewe's milk substitute, Ewelac, or a homogenate of calcium caseinate, Casilan, were studied. Two milk substitutes, one with a long and one with a short clotting time were compared in terms of their effects on the incidence of diarrhoea.

2. The location of the liquid feeds in the stomach was studied radiologically.

3. In both experiments the sucking behaviour of the lambs was closely related to the functioning of the oesophageal groove reflex and performance of the lambs. In the first experiment the milk substitute consistently entered the abomasum in seven of the ten individually fed lambs and in twelve of the twenty-two group-fed lambs. The corresponding figures for the second experiment were twenty-two of the twenty-four individually fed and thirty-four of the fifty group-fed lambs.

4. When the milk substitute entered the abomasum it always did so throughout the fattening period even in those instances where the milk had been withheld for I month.

5. Poor sucking, low milk consumption and the entry of the milk into the rumen resulted in very poor performance by the lambs. Such lambs demonstrated a non-specific unthriftiness similar to the 'tail enders' sometimes observed with lambs reared with ewes.

6. Continued feeding with either the milk substitute or casein homogenate with a lowprotein creep feed did not improve performance.

7. The clotting time of the milk substitute did not appear to influence the incidence of diarrhoea among the lambs.
\end{abstract}

There is at present considerable interest in the extent to which the functioning of the oesophageal groove reflex in young ruminants may be exploited by means of liquid feeding to by-pass the rumen. Ørskov \& Benzie (1969) have studied this phenomenon and the factors which effect the closure of the groove. Their results indicate that the functioning of the groove is a reflex action unrelated to the chemical and physical stimuli associated with the swallowing of fluids. These workers maintain that both a stimulus and the conditioning of the animals are required to ensure its functioning. The nature of the stimulus is still unknown. The extent to which the closure of the groove occurs in lambs that have been trained to suck from a bulk dispenser as compared with those sucking from individual feeders is of considerable importance in the intensive fattening of early-weaned lambs. The results of a number of workers, in particular Welch, Vander Noot \& Gilbreath (1963), Brown (1964), Large (1965) and Owen, Davies \& Ridgman (1969), have indicated the problems associated with the 
artificial rearing of lambs weaned at birth and the commercial feasibility of using this system to fatten lambs by a judicious combination of liquid and solid feeding. The present paper reports on studies conducted to compare the functioning of the oesophageal groove reflex in lambs sucking from individual feeders with that in lambs sucking from bulk dispensers. In addition, the extent to which the oesophageal groove operates throughout the fattening period and its use as a nutrient-saving device in intensive production of fat lambs were studied.

\section{EXPERIMENTAL}

\section{Animals and treatments}

Two experiments were done. Thirty-two greyface (Border Leicester ${ }^{\lambda} \times$ Blackface 9 ) lambs were used in Expt $\mathrm{x}$. Ten of the lambs were weaned at $3 \mathrm{~d}$ of age and individually penned. They were trained to suck from individual bottles fitted with teats and were fed ad lib. on a reconstituted ewe's milk replacer Ewelac (McCormac Products Ltd, Killeshandra, Co. Cavan) up to slaughter; no solid food was offered. The composition of the Ewelac was $30 \%$ fat, $24.5 \%$ protein and $<0.25 \%$ crude fibre on a dry-matter basis. At the end of the Ist week, when the lambs had adjusted to the milk substitute, five of them continued to receive the Ewelac that had a normal clotting time of $3 \mathrm{~min}$, and five were fed on Ewelac that had a clotting time in excess of 24 min. The purpose was to ascertain if a ewe's milk substitute so manufactured as to have a very long clotting time, contributed to the incidence of diarrhoea among early-weaned lambs fed $a d$ lib. The incidence of scouring and the consistency of the faeces were noted daily for each lamb. At the end of 3 weeks all ten lambs continued to receive the milk substitute with the normal clotting time.

The remaining twenty-two lambs were weaned between 6 and $14 \mathrm{~d}$ of age and were trained to suck from a bulk dispenser. The dispenser used was the Supersuckler manufactured by Volac Ltd, Crayden Old Farm, Wendy, Near Royston, Herts. These lambs were also given the milk substitute $a d$ lib. A pelleted creep feed $(\mathrm{OH})$, the composition of which is given in Table I was introduced to the lambs $3 \mathrm{~d}$ after the beginning of the experiment. Owing to the age differences of the lambs at the commencement of the experiment there were considerable differences in initial live weights. This fact, together with variations in milk substitute and creep feed intakes, resulted in some lambs being considerably heavier after 6 weeks on the experiment. For the purpose of the subsequent treatments it was therefore decided to wean the first eleven lambs reaching an average of $19 \mathrm{~kg}$ live weight on to a diet of creep feed only. These eleven lambs were then $55 \pm 2 \mathrm{~d}$ of age. In the statistical analysis of the results adjustments were made for age differences in assessing performance differences. However, for radiological purposes the lambs were subsequently offered the milk on two occasions. The other eleven lambs continued to get the milk substitute and the solid food ad lib. All lambs were X-rayed on four occasions, twice before being put on the treatments at $19 \mathrm{~kg}$ live weight and twice before they were slaughtered at approximately $36 \mathrm{~kg}$ live weight. The mean age of the lambs at slaughter was IOI $\pm 2 \mathrm{~d}$.

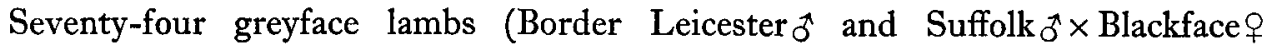


crosses), weaned at $48 \mathrm{~h}$, were used in Expt 2. Twenty-four of the lambs were trained to suck the ewe's milk substitute from individual bottles and fifty were trained to suck from three bulk dispensers. All of the lambs were fed ad lib. on the milk substitute until they reached $\mathrm{I} 7 \mathrm{~kg}$ live weight, which corresponded to $4 \mathrm{I} \pm 2 \mathrm{~d}$ of age. Of the twenty-four individually fed lambs, one lamb died before radiological observations were begun, and consequently three further lambs were not placed on the subsequent treatments in order to allow an even number of lambs per treatment. Although

Table I. Components (\%) and proximate analysis (\%) of the pelleted roughage-concentrate creep feeds, OH, HP and LP, offered to the lambs

\begin{tabular}{|c|c|c|c|}
\hline & $\mathrm{OH}$ & HP & LP \\
\hline Oat hulls & $27 \cdot 5$ & $30 \cdot 0$ & $32 \cdot 0$ \\
\hline Grass meal & $20 \cdot 0$ & $15 \cdot 0$ & $15 \cdot 0$ \\
\hline Maize & 40.0 & $3 \mathbf{I}^{\circ} \mathrm{O}$ & $49^{\circ} \circ$ \\
\hline Soya-bean meal & $7 \cdot 5$ & $20 \cdot 0$ & - \\
\hline Molasses & 2.5 & $2 \cdot 0$ & $2 \cdot 0$ \\
\hline Mineral and vitamin mixture* & $2 \cdot 5$ & $2 \cdot 0$ & $2 \cdot 0$ \\
\hline \multicolumn{4}{|l|}{ Proximate analysis: } \\
\hline Crude protein & $12 \cdot 0$ & $15 \cdot 4$ & $7 \cdot 5$ \\
\hline Crude fibre & $14 \cdot 1$ & $15 \cdot 4$ & 14.8 \\
\hline Ether extractives & 1.8 & $\mathrm{I} \cdot 8$ & 2.8 \\
\hline
\end{tabular}

- Providing (per $\mathrm{kg}$ diet): iodized $\mathrm{NaCl}, 5.0 \mathrm{~g} ; \mathrm{CoCO}_{3} 13.4 \mathrm{mg}$; vitamin $\mathrm{A}, 3000$ i.u.; ergocalciferol, 500 i.u.; vitamin E, $33.0 \mathrm{mg}$. The amount of dicalcium phosphate was varied to provide a constant calcium to phosphorus ratio for each diet.

radiological observations were made on these three lambs in the initial phase of the experiment, results for performance were not recorded. Thus twenty individually fed and twenty-eight group-fed lambs that attained this live weight were randomized among the following four treatments:

(I) A pelleted roughage-concentrate creep feed containing $15 \%$ crude protein (high-protein, HP).

(2) The milk substitute together with the same feed as in (I).

(3) The milk substitute plus a pelleted roughage-concentrate feed containing $7.5 \%$ crude protein (low-protein, LP).

(4) A homogenate of Casilan (Glaxo Laboratories Ltd, Greenford, Middlesex) and the low-protein feed as in (3). The Casilan contained $90 \%$ protein, $\mathrm{I} \cdot 8 \%$ fat, $0.4 \%$ glyceryl mono-oleate, $4.0 \%$ moisture and $3.8 \%$ mineral salts.

Sixteen group-fed lambs that were rejected were given the diet used in treatment $I$.

The compositions of the pelleted roughage-concentrate feeds containing $15 \%$ and $7.5 \%$ crude protein are given in Table 1 . The solid food and the liquid diets were offered $a d ~ l i b$. The lambs were X-rayed at approximately 3 -week intervals before and after being put on the different treatments.

The lamb pens had slatted wooden floors and a supply of fresh clean water was available. The dilution rate for the reconstituted milk substitute was $20 \%(\mathrm{w} / \mathrm{v})$ and for the homogenate of casein $12 \%(w / v)$. 


\section{Radiological procedure}

A suspension (20\%, w/v) of barium sulphate (Damancy Micropaque) was added as a marker to the liquid feeds for X-ray purposes. In Expt I all the lambs were studied on a fixed machine with an output of $200 \mathrm{kV}$ and $1000 \mathrm{~mA}$. Standard screens and films were used. Exposure factors varied from $55 \mathrm{kV}$ at $4 \mathrm{~mA} / \mathrm{s}$ without a grid for small lambs to $75 \mathrm{kV}$ at $20 \mathrm{~mA} / \mathrm{s}$ using a stationary fine-line grid for large lambs.

In Expt 2 a portable machine with an output of $85 \mathrm{kV}$ and ${ }_{5} \mathrm{~mA}$ was used. When the lambs were fully grown, however, the exposure times necessary with this machine were unduly long and the fixed machine was used. The lambs were positioned on their backs to obtain a ventro-dorsal view of the abdomen. In this position the abomasum has a characteristic outline and its long axis is directed from left to right. Examples of the radiographs are shown in $\mathrm{Pl}$. $I$.

\section{Measurement of clotting time}

A solution of rennet was prepared by dissolving I $\mathrm{ml}$ rennet extract (Smiths Pharmaceuticals, Dublin) in $100 \mathrm{ml}$ distilled water; $1 \mathrm{ml}$ of this solution was then added to $10 \mathrm{ml}$ of reconstituted milk (12.5\% solids) and incubated at $37^{\circ}$. Milk that coagulated within 3 min was described as having a good clotting time, whereas when coagulation took longer than 24 min clotting time was described as poor.

\section{RESULTS}

The results of Expt I showing the incidence of atypical sucking and the location of $\mathrm{BaSO}_{4}$ in the stomach of individually fed and group-fed lambs are shown in Table 2. Contrary to what one might expect, individually fed lambs were more easily trained to suck than those offered the milk from a bulk dispenser. As a result, the milk substitute consistently entered the abomasum in seven of the ten lambs individually fed and in twelve of the twenty-two group-fed lambs. The $\left(\chi^{2}\right)$ test on proportions showed that this difference between individually and group-fed lambs was not significant. It should be emphasized that all the twenty-two group-fed lambs were sucking from the same milk dispenser until eleven were weaned on to solid feed. It is of interest that with the eleven lambs weaned from the feeder and offered milk substitute on two subsequent occasions the milk continued to enter the abomasum as previously, but this did not occur with those that had displayed atypical sucking action.

It was observed that milk entered the rumen of lambs that were seen to bite the teats, and when intermittent biting and sucking was evident the milk entered both rumen and abomasum. In the case of the group-fed lambs no consistent pattern was observed in terms of the age of lambs at weaning and their ability to suck properly. It was, however, increasingly difficult to train lambs weaned after $3 \mathrm{~d}$ of age.

The clotting time of the milk substitute did not have any effect on intake or on performance of the lambs. The mean daily intakes were $0.4 \mathrm{I} \mathrm{kg}$ and $0.37 \mathrm{~kg}$ dry matter from the milk substitute for the 'normal' and 'poor' milks respectively. Nor did the milk with the poor clotting time increase the incidence of diarrhoea. All the 
Vol. $26 \quad$ Functioning of oesophageal groove reflex
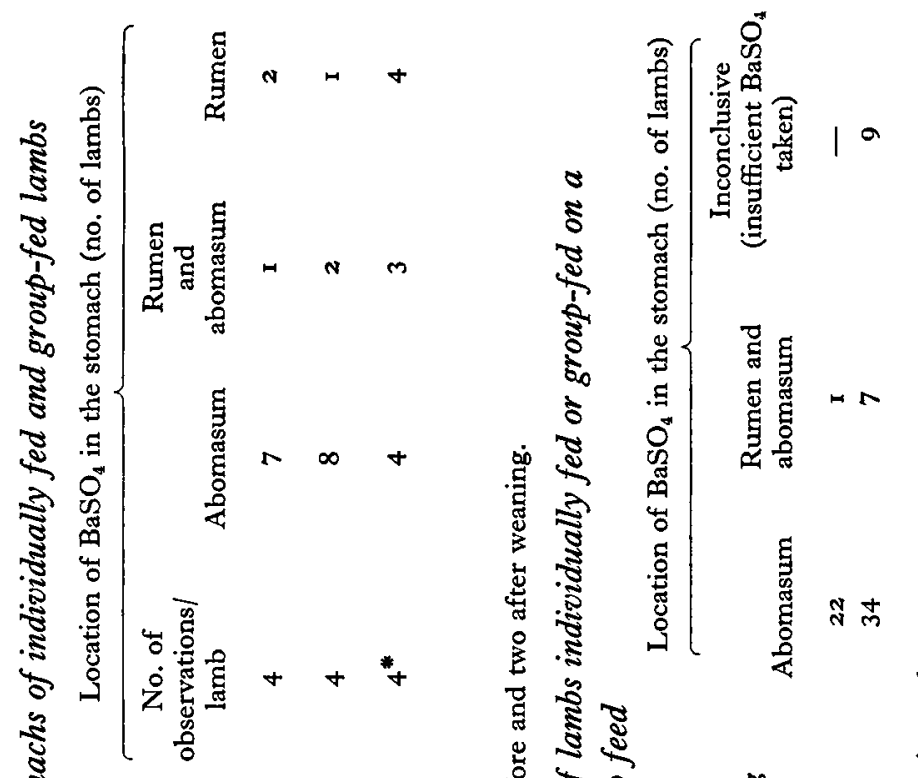

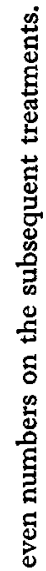
녕

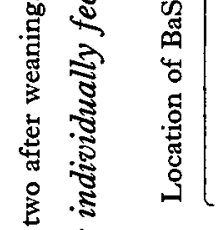

喿

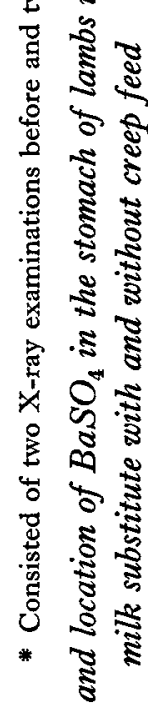



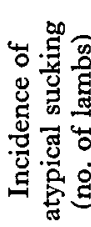

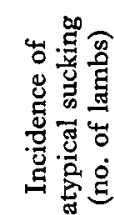

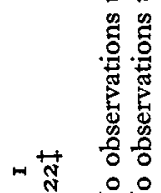

焉

ป⿱艹

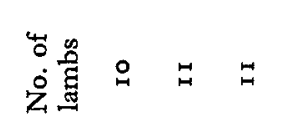

हี

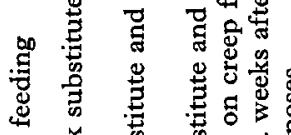

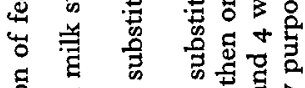

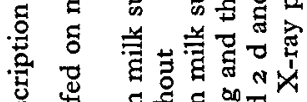

总密

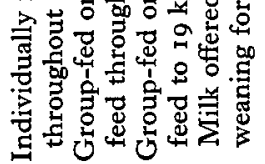



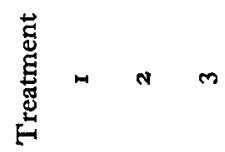

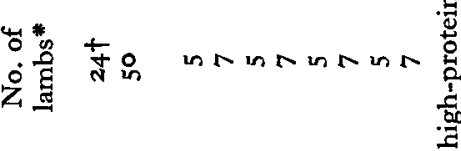

定

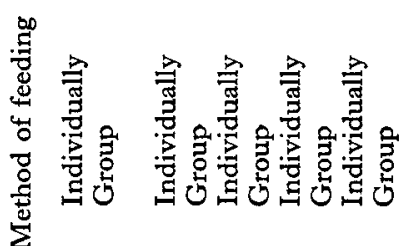

递

害

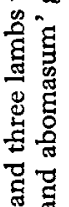

कृ

苛

焉

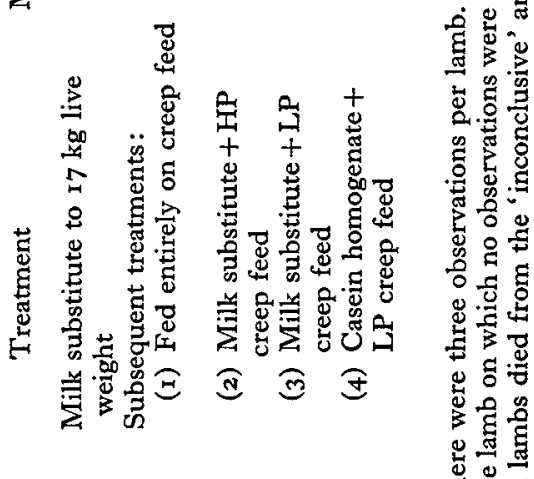

F啳 
害芦总总

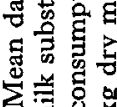

ஸூำ

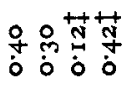

|

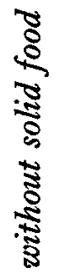

द्व

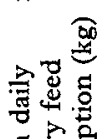

竞离

I

$1|1|$

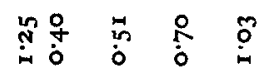

胥

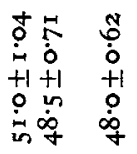

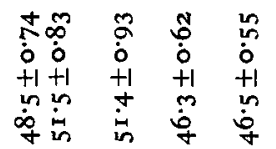

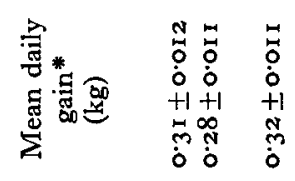

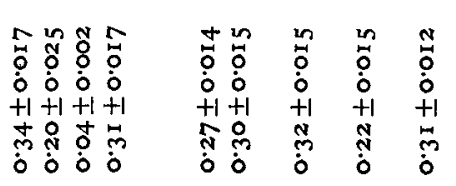

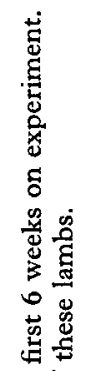

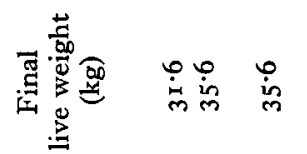

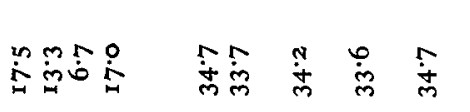

象

है

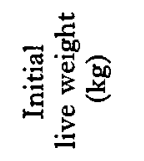

$\underset{+\infty}{m} \stackrel{0}{\infty}$

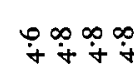

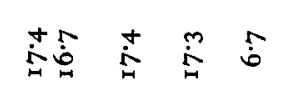

疍

突 sis

$\stackrel{5}{5}$<smiles>CCC</smiles>

岁量

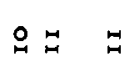

웧에용

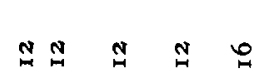

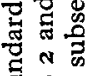

跑点

志䟢

:

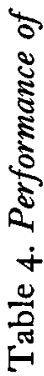
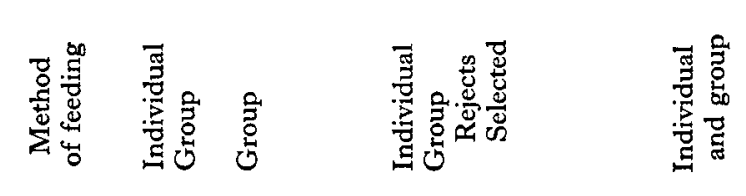

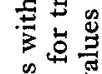
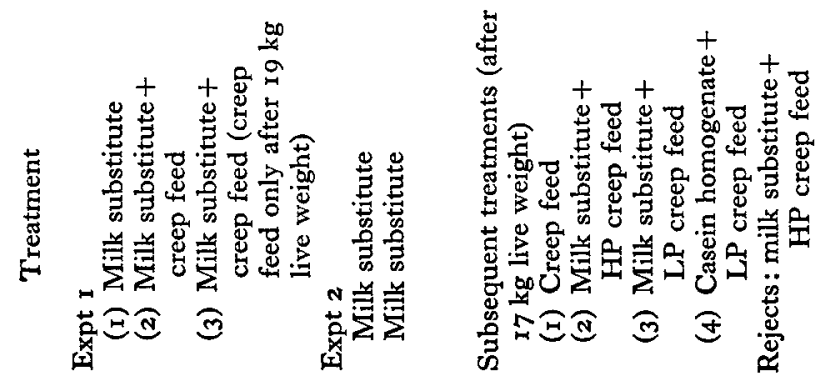
lambs suffered from intermittent diarrhoea, and a total of twenty-three incidences of diarrhoea were recorded for those on the 'normal' milk compared with eleven for those on the 'poor' milk. The higher incidence of diarrhoea for the lambs on the normal milk reflected a particularly high incidence with two lambs on that treatment.

Details of the sucking pattern and location of the $\mathrm{BaSO}_{4}$ in the stomachs of the individually fed and group-fed lambs in Expt 2 are given in Table 3. In this experiment the milk consistently entered the abomasum in $92 \%$ of the individually fed and $68 \%$ of the group-fed lambs. By the $\left(\chi^{2}\right)$ test this difference was significant $(P<0.05)$.

As in Expt $I$, the incidence of atypical sucking was closely related to the variable location of the milk in the different compartments of the stomach. A total of twentytwo lambs displayed an atypical sucking pattern in the group-fed lambs and six of them died during the early stages of the experiment; one lamb fed individually showed atypical sucking. The cause of death appeared to be entirely an inadequate intake of milk. It will be seen from Table 3 that throughout the subsequent treatments the milk substitute and casein homogenate continued to enter the abomasum up to the time of slaughter.

Results for performance of the individually fed and group-fed lambs in both experiments are given in Table 4. Owing to the very poor performance and the death of six lambs, twenty-two lambs in Expt 2 were excluded from the various treatments. There was no significant difference in the overall performance of the lambs on any of the three treatments. Killing out percentage was highest for the lambs given the milk substitute only.

In Expt 2 the live-weight gains of the lambs on the various treatments were very similar, with the exception of those given the casein homogenate, the intake of which was very low. The performance of the lambs on this treatment was significantly lower $(P<0.01)$. No significant differences were observed between results with a highprotein and a low-protein roughage-concentrate diet in conjunction with the milk substitute. The performance of the sixteen rejected lambs is of particular interest; their live-weight gain was negligible before the introduction of the solid food. This reflected a very low intake of milk, which in the circumstances could not be measured accurately. However, the subsequent value of $0.12 \mathrm{~kg}$ milk substitute dry matter is probably very close to what they were previously consuming.

\section{DISCUSSION}

The functioning of the oesophageal groove reflex in young ruminants may have widespread applications in ruminant studies, as indicated by Ørskov \& Fraser (1969) and Ørskov, Benzie \& Kay (1970). In the artificial rearing of lambs as part of an intensive indoor fattening system, it is most important to ascertain the extent to which the groove functions in lambs trained to suck as individuals or in groups. This was a primary object of the present work.

In both experiments the incidence of the milk's entering the abomasum was greater with individually fed than with group-fed lambs. This in turn reflects a lesser incidence of atypical sucking among individually suckled lambs. It is difficult to 
suggest why individually fed lambs respond better to the training routine. Probably a number of factors, including the type of feeder, are involved. It is common experience that some lambs are trained to suck more easily than others, and therefore considerably more attention was given to those that responded poorly to the training. The act of sucking, and the functioning of the groove reflex, did not appear to be conditioned by the presence of any one person feeding the lambs. In the course of this work there were three and sometimes four people engaged in the feeding and care of the lambs.

In Expt I there appeared to be no relationship between the age of the lambs at weaning and the incidence of atypical sucking. However, the authors did find it more difficult to train the older lambs to suck. The relatively small number of lambs involved in this experiment and the fact that none of the lambs over $3 \mathrm{~d}$ of age was individually fed limited our observations on the impact of age at weaning from the ewe, on the response to artificial rearing and, in particular, on the incidence of atypical sucking. One further factor which may have contributed to a more frequent appearance of $\mathrm{BaSO}_{4}$ in parts of the stomach other than the abomasum of the lambs in Expt I was the X-raying procedure. As indicated earlier, these lambs were X-rayed with a fixed machine. This involved transporting the lambs a distance of approximately $9.6 \mathrm{~km}$ and then feeding them individually immediately before they were $\mathrm{X}$-rayed. The lambs were obviously conscious of the change in environment and conditions, and occasionally the groove reflex did not function. Nevertheless, the incidence of atypical sucking, as observed regularly during normal feeding, was closely correlated with the location of the $\mathrm{BaSO}_{4}$ in the stomach. The $\mathrm{BaSO}_{4}$-milk suspension was subsequently offered through their feeders before they were $\mathrm{X}$-rayed. Of the eleven lambs in Expt I which were weaned on to the solid feed, four had previously sucked properly and the $\mathrm{BaSO}_{4}$ was consistently located in the abomasum. Subsequently when on two occasions these lambs were offered the milk substitute, it was again located in the abomasum. Similar results have been reported by Ørskov et al. (1970).

A comparison of the radiological results presented in Tables 2 and 3 with the results for performance in Table 4 demonstrates the importance of the proper functioning of the oesophageal groove reflex in the early stages of feeding with a ewe's milk substitute. This is particularly clear in the results of Expt 2. Unfortunately in Expt I it was not possible to measure individual intakes of milk for the twenty-two group-fed lambs. The very poor initial performance of the sixteen so-called 'rejected' lambs in Expt 2 is particularly obvious. On the other hand, the live-weight gains of the ten individually fed lambs that received milk substitute throughout life in Expt I and that of the fortyeight lambs fed on the milk substitute to $17 \mathrm{~kg}$ live weight in Expt 2 were very good. Perhaps the most important finding in this work in relation to the incidence of atypical sucking behaviour and the non-functioning of the oesophageal groove reflex is what might be appropriately termed a maladjustment syndrome (Lawlor \& Kealy, 1971). The ultimate problem is that these lambs do not consume enough milk, even sometimes to sustain life. An interesting feature is that they do not respond to persistent attempts to train them to suck. It is difficult to suggest why this should be so. It may be that these lambs did not receive an adequate supply of colostrum at birth 
or were not suckled at all by the ewe. Whereas the incidence of maladjustment may be greater with artificial rearing than with natural rearing, one is justified in speculating that it may be a contributory factor to the phenomenon of non-specific unthriftiness in naturally reared lambs.

The method of overcoming the problem of maladjustment in lambs reared artificially under commercial conditions would appear to be entirely that of offering a solid palatable food at an early stage. These lambs consume the solid food much more readily than lambs which suck well and consume large quantities of milk. The compensatory growth effect of giving the solid diet to the sixteen rejected lambs in Expt 2 was remarkable. In the first experiment the lambs that did not suck well were also observed to have consumed much more of the solid food and, as a result, performed reasonably well.

The result of Expt 2 indicated no advantage in continuing to give the milk substitute with a low-protein or high-protein diet. The growth rate of the lambs given the homogenized calcium caseinate was very poor. These lambs consumed very little calcium caseinate, and the compensatory intake of solid food was inadequate to support a better rate of growth. Despite the fact that the calcium caseinate offered was of $12 \%$ dilution $(\mathrm{w} / \mathrm{v})$, it still had a gelatinous consistency and the lambs appeared to find it unpalatable. The radiological studies indicate, however, that it was located in the abomasum. The main conclusion to be reached from the performance of the lambs is that protein was not a limiting factor in any of the treatments. The calculated mean daily intakes of protein were $193,160,127$ and $233 \mathrm{~g}$ for the HP, milk substitute plus HP, milk substitute plus LP and casein homogenate plus LP treatments respectively. The number of lambs available for the experiment did not permit a further treatment to compare performance on a low-protein diet.

Considerable work has been done by Large (1965), Davies \& Owen (1967) and Owen et al. (1969) on various aspects of the optimum and economical combinations of milk substitute and creep feed to be recommended in artificial rearing. Because of the nature of our work, a comparison of performance would not be entirely valid. However, with the exception of the maladjusted lambs and those given calcium caseinate, the performance in terms of growth rate and feed conversion efficiency was excellent. When the protein requirement of the young lamb is more precisely known it may be possible to use a cheap source of protein in a liquid form in conjunction with a lowprotein pelleted roughage-concentrate feed for intensive production of lambs.

We are grateful to Dr J. P. Crowley of the Physiology Department for his valuable advice and co-operation during this work and to Dr D. Harrington for his statistical analysis of the results. We wish to thank MacCormac Products Ltd, Killeshandra, Co. Cavan, for supplies of Ewelac and Glaxo Laboratories Ltd, Greenford, Middlesex, for supplying the Casilan. We are grateful to the Unilever Group for a financial contribution towards this work. We thank Colm McDonnell for his technical assistance. 


\section{REFERENCES}

Brown, T. H. (1964). J. agric. Sci., Camb. 63, г9г.

Davies, D. A. R. \& Owen, J. B. (1967). Anim. Prod. 9, 5or.

Large, R. V. (1965). F. agric. Sci., Camb. 65, Ior.

Lawlor, M. J. \& Kealy, J. K. (1971). Vet. Rec. 88, 260.

Ørskov, E. R. \& Benzie, D. (r969). Br. F. Nutr. 23, 415.

Ørskov, E. R., Benzie, D. \& Kay, R. N. B. (1 970). Br. F. Nutr. 24, 785.

Ørskov, E. R. \& Fraser, C. (r969). F. agric. Sci., Camb. 73, 469.

Owen, J. B., Davies, D. A. R. \& Ridgman, W. J. (1969). Anim. Prod. x1, I.

Welch, J. G., Vander Noot, G. W. \& Gilbreath, R. L. (1963). F. Anim. Sci. 22, 155.

\section{EXPLANATION OF PLATE}

Radiographs showing location of barium sulphate in the stomachs of lambs. The barium sulphate was offered as a suspension with ewe's milk substitute either from a teat-bottle or a bulk dispenser. In $(A)$ it is located in the rumen, $(B)$ shows it in the abomasum and in $(C)$ it is present in the rumen and abomasum. The radiographs were taken with the lambs held on their backs. 


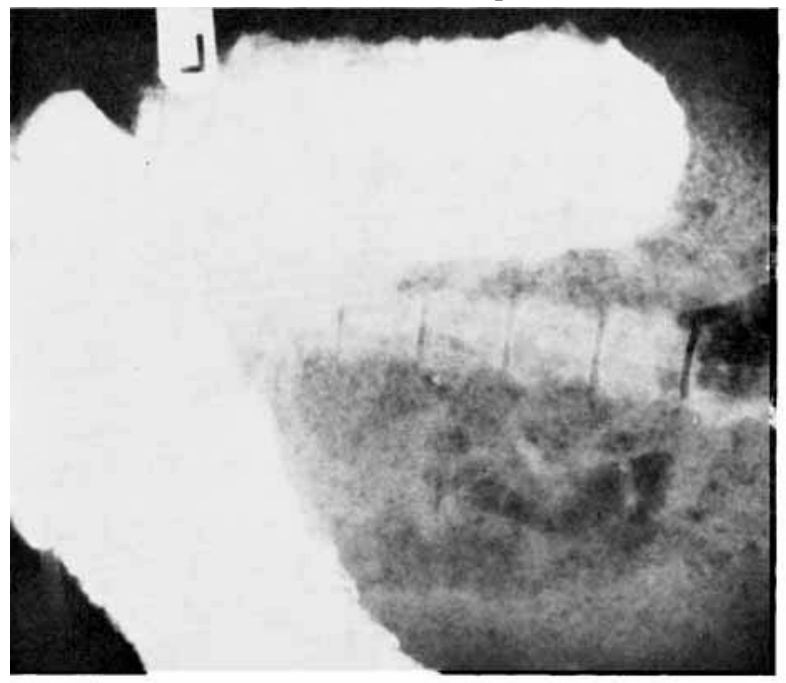

0

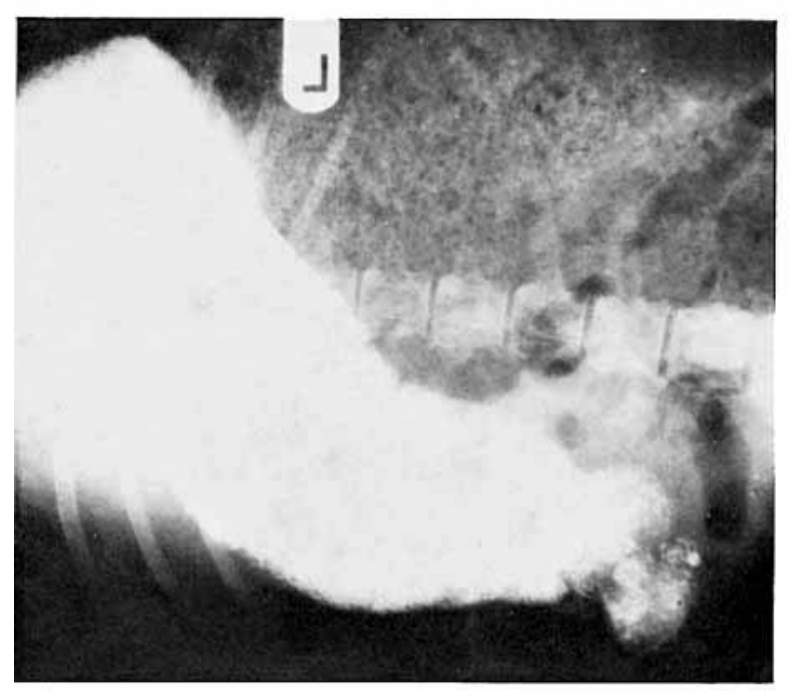

$m$

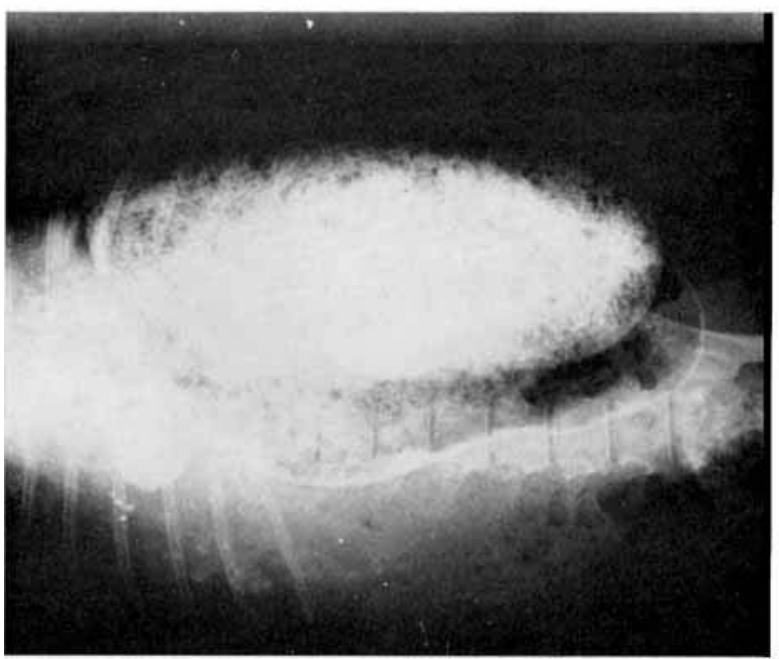

$\varangle$

M. J. LAWLOR, S. P. HOPKINS AND J. K. KEALY 